Kong. Res. J. 4(1) : 55-58, 2017

ISSN 2349-2694

Kongunadu Arts and Science College, Coimbatore.

\title{
THE POEMS OF WILLIAM WORDSWORTH: AN ECOCRITICAL OVERVIEW
}

\author{
Vasuki, A. \\ Department of English, Agni college of Technology, Chennai. \\ E.mail: samsoftit1984@gmail.com
}

\begin{abstract}
Eco-criticism emerged in the 1990's and the critics changed their angles of vision and examined the works of art by focusing on the relationship between man and Nature. William Words worth, in particular, became the key icons of eco-critical studies. Wordsworth was a major English Romantic poet who has been considered as a forerunner of English Romanticism. His views towards Nature and man's treatment of Nature have supported his position as an important icon of eco-critical studies. His fame lies in the general belief that he has been viewed as a Nature poet who viewed Nature superior to humans. In other words, his views about Nature and his poems seek to heal the long-forgotten wounds of Nature in the hope of reaching unification between man and Nature. With the emergence of Eco-criticism as a new critical approach in the 1990's, Romantic poetry, in general, and William Wordsworth, in particular, became the icons of eco-critical studies. He was the foremost Romantic poet who cared for the creation of symbiosis between man and Nature. William Wordsworth was a major English Romantic poet who is considered as a forerunner of English Romanticism. His contributions to the repository of English literature are undoubtedly a token of his greatness among his contemporaries. His views towards Nature and man's treatment of Nature have supported his position as an important icon of eco-critical studies. His fame lies in the general belief that he has been viewed as England's greatest Nature poet who viewed Nature superior to human being whose survival is dependent upon Nature. Wordsworth intends to show the value of survival of human being in Nature. Though literary critics talked about the eco-critical concepts in the past, the present paper highlights a recent literary approach to Eco-criticism studies, "the relationship between literature and physical environment" in the poems of William Wordsworth.
\end{abstract}

Keywords: British Poetry, Wordsworth, Ecocriticism.

William Wordsworth was a major Romantic poet, based in the Lake District, England. His poems are frequently inspired by the beauty of nature and he is known as one of the greatest English poets who created a more spontaneous and emotional poetry. It sought to depict the beauty of nature and the quintessential depth of human emotion. In the preface to Lyrical Ballads , Wordsworth writes of poetry that it is "the spontaneous overflow of powerful feelings: it takes its origin from emotion recollected in tranquillity. He developed a great love for nature, spending many hours walking in the fells of the Lake District. William Wordsworth was born on 7 April 1770 in Cocker mouth, Cumberland, in the Lake District.The magnificent landscape deeply affected Wordsworth's imagination and gave him a love of nature.He also became very close to his sister, Dorothy, who would later become a poet in her own right. Wordsworth.

"Ecocriticism is the study of the relationship between literature and the physical environment (Glotfely and Fromm, 1996)"
Eco-criticism emerged in the dawn of an era which environmental pollution and industrial destructions and decay is a serious problem of humanity. Eco-critical theory investigates the relationship between human activities and the natural world, particularly in terms of the influence of each upon the other. Within this broad theoretical field, eco-feminist theory studies women's particular impact on the relationships between the human and natural worlds, and women's potentials to promote the desirable human relationships to the natural world as a way to get over the environmental crisis today. When it foremost stresses sensual and spiritual experience with the outer world for individual and cultural changes, the function of art as healing power is stressed. This is an effort for the recovery of human organic or primordial unity with nature in which the distinction between subjectivity and objectivity blurs. Newborn the Eco-criticism is, it tries to discover and highlight the links between ecology and other fields of study like film, ethics, history, psychology, women's studies, Native American Studies and literature. Eco-criticism emerged in the dawn of an era which environmental 
pollution and industrial destructions and decay is a serious problem of humanity

Wordsworth poetic process is that which the internal makes external. In his poetry external nature is in connection with the internal feelings of the poet This aesthetic process is highly important to reveal Wordsworth attempt to bridge the gap between Nature and man. The poetic persona whom we identify with Wordsworth himself, takes solace and peace at the bosom of nature. Wordsworth poetry is not only the reflection of poet's spiritual dimension but a fact that proves Wordsworth ties with Nature.

For Romantic poets, the imagination is a process of the mind that is deeply emotional and nearly indescribable, which is why it is such a prominent theme in their poems. For critics who study Romantic poetry, the definition of imagination is malleable, which makes for an attractive topic and greatly differentiated criticism. Wordsworth was one of the Romantic poets most intent on interpreting, defining, and exploring the imagination. Wordsworth's preface to Lyrical Ballads the poet intends to link "thought-forms" with "material forms" of daily living; that is, Wordsworth connects the world of real objects to the inner workings of his mind. . Even in Wordsworth's earlier projects, he is attentive to how one's mind affects one's surroundings. Wordsworth places the speaker in the middle of Nature and shows that Nature is right and loyal to human being in its turn and it is man who should take the blame for the broken bond between him/her and Nature:

"I heard a thousand blended notes, While in a grove I sate reclined, In that sweet mood when pleasant thoughts Bring sad thoughts to the mind."

"Lyrical Ballads includes some of his best known poems, such as, "Lines Composed A Few Miles above Tintern Abbey", "A Slumber Did my Spirit Seal".

"A slumber did my spirit seal;

I had no human fears:

She seemed a thing that could not feel

The touch of earthly years.

No motion has she now, no force;

She neither hears nor sees;

Rolled round in earth's diurnal course,

With rocks, and stones, and trees."

Elsewhere, in The Ruined Cottage, there is a reference to Nature's bestowing her favours upon man despite man's disrespectful treatment of nature and his/her disturbing the ecosystem: ...

“Beside yon spring I stood

And eyed its waters till we seemed to feel

One sadness, they and I. For them a bond

Of brotherhood is broken: time has been

When every day the touch of human hand

Disturbed their stillness, and they ministered

To human comfort. ........"

These lines can support Wordsworth's ecological position as a poet of Nature and serve as a justification for the union of the above-mentioned critics who rely on Wordsworth's contributions to the rise of the ecological awareness of human beings.

The "Preface to Lyrical Ballads" is not a systematic poetics, but a partly polemical, partly pedantic, and still problematic statement of Wordsworth's beliefs about poetry and poetic language. The preface in all its versions is highly discursive, the poet "thinking aloud" in an attempt to formulate ideas about poetry based on poems he has already written. It is important to remember when reading the preface that it both chronologically and logically follows the composition of most of the poems. The two central ideas of the preface are the need for reforming poetic diction-which, according to Wordsworth, had become far too artificial-and the role of the poet in society, which Wordsworth saw as having become too marginal. He had also come to the conclusion that the troubles of society were specifically urban in nature. This view finds eloquent expression in Wordsworth's most powerful early poem, "Tintern Abbey." Thinking of the way in which his memories of the Wye River valley had sustained him, Wordsworth wrote:

"Though absent long,

These forms of beauty have not been to me,

As is a landscape to a blind man's eye:

But oft, in lonely rooms, and mid the din

Of towns and cities, I have owed to them,

In hours of weariness, sensations sweet".

The poem concludes with a meditation on the power of nature to prevail against the false and superficial "dreary intercourse of daily life" that Wordsworth associated with city life, especially literary life in London. In the preface, Wordsworth characterized those forces as acting against the elevation of mind in which the poet specializes, and he identified them with urban life.He published another important volume of poetry "Poems, in Two Volumes", this included famous poems such as; "The 
Daffodils”, “My Heart Leaps Up”, “Ode: Intimations of Immortality".

"I wandered lonely as a cloud, That floats on high o'er vales and hills, When all at once I saw a crowd, A host, of golden daffodils;"

Accordingly, the ballad is a spiritual dimension but a fact that proves Wordsworth ties with Nature. "Lines Written in Early Spring" is analyzed from Eco-criticism lines. While he watches the harmonious music of Nature and thinks of disharmony of man with Nature, he mourns the alienation of man with Nature. He tells about Nature's dynamic development when he describes how the periwinkle trains its branches through the grass. The poet emphasizes the harmony in the Nature. Invited to reunion with Nature, Wordsworth rejects anthropocentrism resulting from industrial progress in which man is superior to Nature. He encourages bio-centrism in which man and Nature are in harmony and equality. Accordingly, the interconnectedness between man and Nature can save both

Although Eco-criticism is in infancy and has developed newly in our age, literature has mirrored humankind's concern towards nature since centuries ago. In this comparative study, poems of two Romantic poets had been discussed from deep Ecocritical lens because nature is the main personal and poetic concern of them. Deep ecology emphasizes the monism of man and nature: "the shift from a humancentred to a nature-centred system of values is the core of radicalism attributed to deep ecology"

His poem "Lines Written in Early Spring" juxtaposes the sense of threat to destruction of Nature and poet's attempt to rejoin man and Nature. Wordsworth envoys the harmony that exist between natural elements and he mourns disharmony in the relation between man and Nature. From theoretical aspect of deep ecology, Wordsworth demands human being to redefine its relationship with nature. $\mathrm{He}$ invites to self-awareness that leads to identification with Nature. It removes the superior position of man on Nature in the modern age and places him/her in an equal situation

Using Wordsworth's imagination as a lens, one can see how much broader critical approaches have become with the shifting focuses of different theories. And as they explore the imagination, scholars elucidate their modes of inquiry and exemplify the novel aspects of their schools. Although these schools of literary criticism have vastly different methodologies and ofteninconsistent conclusions, as the scope of critical materials continues to expand over time one central issue remains: understanding Wordsworth's imagination in 'The Prelude'. By way of understanding and appraisal, it must first be asked what Wordsworth set out to do and then to what degree he succeeded. It has been remarked that he was one of the giants; almost single-handedly he revivified English poetry from its threatened death from emotional starvation.

By using language to blend the impossible and the actual, he demonstrates the power of the imagination and gives his readers a better understanding of what he desires from reality. In addition to the imagination, the deeper, symbolic meaning of this passage is a key: Wordsworth must come to terms with the disappointment of the hike, an allegory for his coming to terms with many disappointments and unexpected turns in his adult life. Thus, Wordsworth can use situations from the past and from the present, forcing readers to draw meaning from the similarities as well as the differences. His memory calls to mind situations, and his imagination creatively connects them. Wordsworth's emphasis on human being's dependence on Nature for survival is clearly shown in 'The Ruined Cottage', wherein he says:

"At length [towards] the [Cottage I returned] Fondly, and traced with milder interest

That secret spirit of humanity

Which, 'mid the calm oblivious tendencies

Of nature, 'mid her plants, her weeds, and flowers, And silent over-growings, still survived".

One of Wordsworth's finest achievements was that his simple childhood readied his mind to the value of the non-artificial, and he was not slow to appreciate the need for a reform of "poetic" language. Poetry became an immediate and intimate experience told by the experience. Beauty was to be admired for its own sake. Wordsworth's reliance on unaffected speech and action and his deep conviction that simplicity of living was a philosophy harmoniously in agreement with nature wrought a revolution in poetic values. His Preface to the Lyrical Ballads became the symbol and the instrument of romantic revolt. Wordsworth's philosophy of life, his theory of poetry, and his political credo were all intricately connected. A change in one characteristically brought parallel changes in the others. 
In contrast to this belief, several eco-critics reject Wordsworth as an ecological thinker and believe that he values human imagination more than Nature and has an objectified view towards Nature. As a matter of fact, Wordsworth's aim in granting superiority to Nature was an effort to broaden human beings ecological horizons and show that Romantic view of Nature was "a search for holistic or integrated perception, an emphasis on interdependence and relatedness in nature, and an intense desire to restore man to a place of intimate intercourse with the vast organism that constitutes the earth"

Wordsworth is upset with the modern man's neglectful treatment of Nature and shows that the punishment of him/her is the unification of the natural elements from which man is banished; "For this, for everything, we are out of tune; / It moves us not."

Wordsworth attacks "the objectivity of our conventional ways of knowing", doubting about the possibility of a "conversation" between man and the natural objects in the world, where the speaker of the poem says:

"The eye-it cannot choose butsee; We cannot bid the ear be still;

Our bodies feel, where're they be, Against or with our will. ... -

Then ask not wherefore, here, alone, Conversing as I may, I sit upon this old grey stone,
And dream my time away."

Wordsworth is a poet who never seems far from critics' minds. It seems that new generations of critics never tire of evaluating and re-evaluating the ideas found within Wordsworth's poetry, and reinterpreting their significance for a new generation. Towards the end of his life, his disillusionment with the French revolution had made him more conservative in outlook.. He was persuaded to become the nation's poet laureate; despite saying he wouldn't write any poetry as Poet Laureate. Wordsworth is the only Poet Laureate who never wrote poetry during his time as Poet Laureate. It is within this whirlpool of critical voices that Wordsworth's poetry exists for us today. Wordsworth's sonnet, "The World Is Too Much with Us", written in 1802, can be a good justification for argument wherein the speaker says: The world is too much with us; late and soon, Getting and spending, we lay waste our powers: Little we see in Nature that is ours; We have given our hearts away, a sordid boon!

\section{REFERENCES}

Glotfely, C. and H. Fromm, eds (1996). The Ecocriticism Reader. Georgia: University of Georgia Pune.

The complete poetical warne of William Wordsworth.

www. bartleby.com 